Jurnal Keperawatan Silampari

Volume 5, Nomor 1, Desember 2021

e-ISSN: 2581-1975

p-ISSN: 2597-7482

DOI: https://doi.org/10.31539/jks.v5i1.2953

\title{
POSISI PRONASI TERHADAP OKSIGENASI PASIEN COVID-19 DENGAN TERAPI OKSIGEN NON-INVASIF
}

\author{
Komang Noviantari ${ }^{1}$, Sri Yona ${ }^{2}$, Riri Maria ${ }^{3}$ \\ Universitas Indonesia ${ }^{1,2,3}$ \\ k.noviantari@gmail.com ${ }^{1}$
}

\begin{abstract}
ABSTRAK
Penelitian ini bertujuan untuk mengidentifikasi bukti-bukti tentang pengaruh posisi pronasi terhadap oksigenasi pada pasien COVID-19 sadar yang mendapat terapi oksigen non-invasif. Metode penelitian ini adalah penelitian tinjauan sistematis. Penelusuran literatur dari rentang tahun 2020-2021 dilakukan di databased online Science Direct, ProQuest, EBSCOhost, dan PubMed. Hasil penelitian menunjukkan bahwa mayoritas sampel laki-laki $(69,7 \%)$ dengan usia rata-rata di atas 50 tahun dan indeks masa tubuh (IMT) diatas normal $(>23,9)$. Hampir sebagian besar penelitian $(92 \%)$ menunjukan adanya peningkatan oksigenasi pada pasien saat dilakukan posisi pronasi. Durasi posisi pronasi bervariasi dari 35 menit - 12 jam dalam 24 jam. Posisi pronasi dapat meningkatkan oksigenasi pada sebagian besar pasien COVID-19 yang mendapat terapi oksigen non-invasif. Simpulan, Posisi pronasi merupakan intervensi yang aman dan layak diimplementasikan pada pasien COVID-19 sadar namun dengan pemantauan yang ketat dari tenaga kesehatan terlatih.
\end{abstract}

Kata Kunci: COVID-19, Oksigenasi, Posisi Pronasi, Terapi Oksigen Non-Invasif

\section{ABSTRACT}

This study aims to identify evidence on the effect of pronation position on oxygenation in conscious COVID-19 patients receiving non-invasive oxygen therapy. This research method is systematic review research. Literature searches from 2020-2021 were carried out in the online databases of Science Direct, ProQuest, EBSCOhost, and PubMed. The results showed that the majority of the samples were male (69.7\%) with an average age of over 50 years and a body mass index (BMI) above average (>23,9). Most of the studies (92\%) showed an increase in oxygenation in patients when performed in the prone position. The duration of the pronation position varies from 35 minutes -12 hours in 24 hours. In conclusion, the pronation position can improve oxygenation in most COVID-19 patients who receive non-invasive oxygen therapy. In conclusion, the pronation position is an intervention that is safe and feasible to implement in conscious COVID-19 patients but with close monitoring from trained health workers.

Keywords: COVID-19, Oxygenation, Pronation Position, Non-Invasive Oxygen Therapy 


\section{PENDAHULUAN}

COVID-19 merupakan masalah kesehatan utama yang dihadapi dunia saat ini. COVID-19 adalah infeksi saluran pernapasan akut atipikal yang disebabkan oleh severe acute respiratory syndrome coronavirus 2 (SARS-CoV-2) (Parasher, 2020; Peng et al., 2020). Manifestasi klinis awal COVID-19 hampir sama dengan gejala pneumonia yang disebabkan oleh virus lain. Tingkat keparahan gejala COVID-19 berbeda-beda pada setiap pasien, mulai dari tidak mengalami gejala hingga bergejala berat dan penyakit kritis (Lovato et al., 2020; Wang et al., 2021). Gejala umum COVID-19 antara lain batuk, demam, fatigue, nyeri seluruh tubuh, dan sesak napas (Esakandari et al., 2020). Pasien dengan gejala sedang biasanya mengalami sesak napas, peningkatan laju pernapasan serta penurunan saturasi oksigen $\left(\mathrm{SpO}_{2}\right.$ di udara ruang 90-95\%). Sedangkan, pasien dengan penyakit berat mengalami gejala sedang ditambah salah satu diantara gejala berikut: laju pernapasan $>30 \mathrm{kali} / \mathrm{menit}$, distres pernapasan berat, atau $\mathrm{SpO}_{2}$ pada udara ruang <90\% (WHO, 2021; Wu \& McGoogan, 2020).

Progresivitas COVID-19 cukup tinggi, sehingga pada sebagian pasien dengan gejala ringan dengan cepat berkembang menjadi penyakit berat (Wang et al., 2021). Penatalaksanaan penyakit didasarkan pada tingkat keparahan penyakit. Pasien dengan gejala ringan dapat melakukan isolasi mandiri dengan beberapa terapi suportif. Pasien dengan gejala sedang dan berat harus di rawat di rumah sakit dengan monitoring yang tepat (WHO, 2021). Pada pasien yang mengalami gejala gagal napas, terapi oksigen merupakan langkah pertama untuk mengatasinya dan diberikan berdasarkan kebutuhan serta metode yang sesuai. Akan tetapi, tingkat kegagalan perawatan sangat tinggi menyebabkan perburukan kondisi oksigenasi pasien (Ji et al., 2020).

Posisi pronasi merupakan salah satu intervensi yang banyak diterapkan pada pasien Acute Respiratory Distress Syndrome (ARDS) dengan ventilasi mekanis invasif. Implementasi posisi pronasi ini meningkatkan oksigenasi serta mengurangi mortalitas pada pasien ARDS (Valesky \& Chow, 2020). Posisi pronasi dikatakan dapat meningkatkan homogenitas paru, pertukaran gas, dan mekanisme pernapasan yang memungkinkan pengurangan intensitas ventilasi serta mengurangi cedera paru pada pasien ARDS dengan terapi ventilasi mekanis invasif (Guerin et al., 2020). Peningkatan oksigenasi pada posisi pronasi adalah hasil dari kecocokan ventilasi-perfusi yang lebih baik. Bagian dorsal paru-paru (yang secara anatomis memiliki jumlah unit alveolar lebih banyak) terbuka kembali karena tidak terkompresi oleh mediastinum atau rongga perut. Hal ini pada akhirnya mengakibatkan perekrutan lebih banyak gas yang bertukar di alveolar-kapiler paru (Bamford et al., 2020).

Baru-baru ini, posisi pronasi telah diimplementasikan pada pasien COVID-19 sadar yang mengalami penurunan oksigenasi dan mendapat terapi oksigen non-invasif. Berbagai penelitian juga sudah dilakukan untuk mengetahui pengaruh posisi pronasi pada pasien COVID-19. Posisi pronasi dikatakan dapat meningkatkan oksigenasi $\left(\mathrm{SpO}_{2}\right.$, $\mathrm{PaO}_{2}$, dan $\mathrm{PaO}_{2} / \mathrm{FiO}_{2}$ ) serta mengurangi kebutuhan ventilasi invasif pada pasien COVID-19 (Anand et al., 2021; Bamford et al., 2020; Chad \& Sampson, 2020). Tinjauan sistematis ini bertujuan untuk mengidentifikasi bukti tentang pengaruh posisi pronasi terhadap oksigenasi $\left(\mathrm{SpO}_{2}\right.$ dan/atau $\mathrm{PaO}_{2} / \mathrm{FiO}_{2}$ dan/atau $\mathrm{SpO}_{2} / \mathrm{FiO}_{2}$ dan/atau indeks ROX) pada pasien COVID-19 dengan terapi oksigen non-invasif. Tinjauan sistematis tentang pengaruh posisi pronasi pada pasien COVID-19 sudah ada, namun masih sangat terbatas. Tinjauan ini lebih berfokus pada outcome parameter oksigenasi $\left(\mathrm{SpO}_{2}\right.$ dan/atau $\mathrm{PaO}_{2} / \mathrm{FiO}_{2}$ dan/atau $\mathrm{SpO}_{2} / \mathrm{FiO}_{2}$ dan/atau indeks $\left.\mathrm{ROX}\right)$, serta hanya 
pasien dewasa sadar yang mengalami penurunan oksigenasi dan mendapat terapi oksigen non-invasif.

\section{METODE PENELITIAN}

Penelitian ini merupakan tinjauan sistematis. Tinjauan sistematis ini dilakukan untuk mengidentifikasi seluruh artikel penelitian tentang posisi pronasi pada pasien COVID-19 dengan terapi oksigen non-invasif yang terbit dari tahun 2020-2021. Kriteria inklusi adalah sampel penelitian pasien COVID-19 dewasa yang dirawat di rumah sakit dengan terapi oksigen non-invasif; artikel penelitian jenis eksperimental, case control, case series, cohort; artikel teks lengkap berbahasa Inggris; dan artikel yang terbit dua tahun terakhir. Sementara itu, artikel penelitian dengan outcome bukan status oksigenasi dieksklusikan dari penelitian ini.

Penelusuran literatur dilakukan di empat database online yaitu Science Direct, ProQuest, EBSCOhost, dan PubMed pada rentang tanggal 8 hingga 13 April 2021. Penelusuran menggunakan kata kunci (COVID-19 OR SARS-CoV-2) AND (non-invasive oxygenation $O R$ non-invasive ventilation $O R$ non-intubated $O R$ nasal high flow $O R$ CPAP OR non-rebreathing mask OR awake OR conscious) AND (prone position* OR proning). Seleksi artikel melalui tiga tahap. Tahap pertama melakukan skrining judul dan abstrak. Tahap kedua adalah seleksi duplikasi dan teks lengkap tidak berbahasa Inggris. Tahap ketiga adalah seleksi dengan membaca teks lengkap untuk mencari artikel yang sesuai dengan kriteria kelayakan. Artikel dengan jenis artikel review, pasien COVID-19 mendapat terapi oksigen invasif, serta outcome bukan status oksigenasi dieksklusikan. Pada akhirnya, 14 artikel teks lengkap yang memenuhi kriteria kelayakan kemudian dianalisis. Analisis dilakukan dengan menggunakan pendekatan deskriptif. Seluruh artikel ditelaah secara kritis dan dievaluasi untuk penilaian kualitas serta bias.

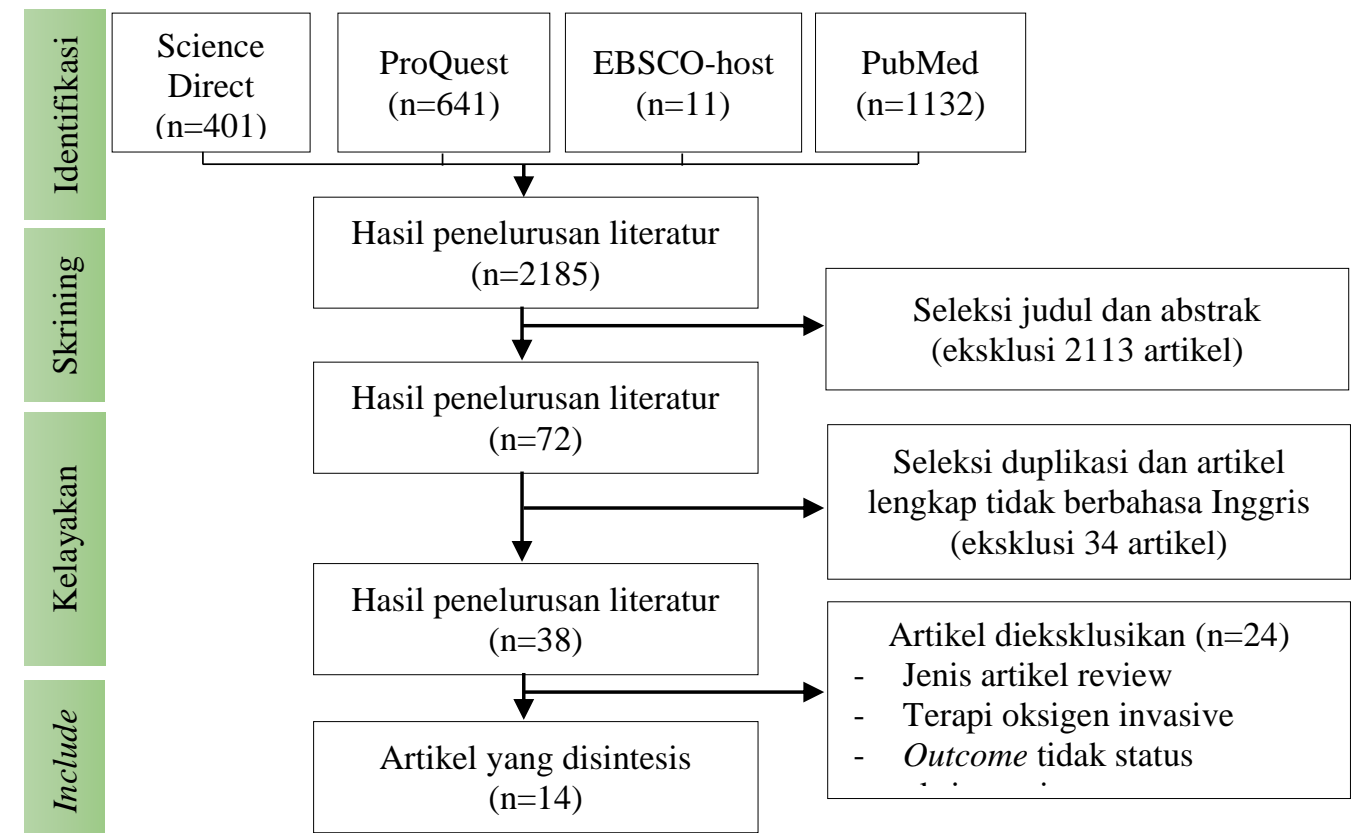

Gambar. 1

Diagram alur penelusuran literatur PRISMA 
Berdasarkan gambar 1, terdapat total 2185 artikel yang teridentifikasi dari hasil penelusuran menggunakan kata kunci yang telah ditetapkan. Setelah melakukan tiga tahap seleksi, hanya 14 artikel yang memenuhi kriteria kelayakan.

\section{HASIL PENELITIAN}

Tabel. 1

Rangkuman Sintesis Artikel Penelitian

\begin{tabular}{|c|c|c|c|c|c|c|c|c|c|}
\hline Penulis & $\begin{array}{c}\text { Tahu } \\
\mathrm{n}\end{array}$ & Desain & $\mathrm{N}$ & $\begin{array}{c}\text { Jenis } \\
\text { Kelamin }\end{array}$ & Usia & IMT & Kontrol & $\begin{array}{c}\text { Durasi } \\
\text { PP }\end{array}$ & $\begin{array}{c}\text { Hasil } \\
\text { Utama }\end{array}$ \\
\hline $\begin{array}{l}\text { Wendt et } \\
\text { al., }\end{array}$ & 2021 & $\mathrm{RR}$ & 31 & $P: 4$ & $\begin{array}{l}62 \pm 1 \\
2\end{array}$ & $31 \pm 5$ & $\begin{array}{l}\text { Tidak } \\
\text { ada }\end{array}$ & - & $\begin{array}{l}\text { Saat } \\
\text { PP: } \uparrow O\end{array}$ \\
\hline $\begin{array}{l}\text { Coppo, et } \\
\text { al. }\end{array}$ & 2020 & $\mathrm{PC}$ & 56 & P: 12 & $\begin{array}{l}57.4 \pm \\
7.4\end{array}$ & $\begin{array}{l}27,5 \pm 3 \\
7\end{array}$ & $\begin{array}{l}\text { Tidak } \\
\text { ada }\end{array}$ & $\begin{array}{l}\text { Paling } \\
\text { sedikit } 3 \\
\text { jam }\end{array}$ & $\begin{array}{l}\text { Saat } \\
\text { PP: } \uparrow O \\
\text { Setelah } \\
:-O\end{array}$ \\
\hline $\begin{array}{l}\text { Dubosh et } \\
\text { al., }\end{array}$ & 2020 & $\mathrm{OC}$ & 22 & $\mathrm{P}: 8$ & $\begin{array}{l}61(50 \\
-65)\end{array}$ & $\begin{array}{l}31,6 \\
(29,3- \\
35,1)\end{array}$ & $\begin{array}{l}\text { Tidak } \\
\text { ada }\end{array}$ & $\begin{array}{l}\text { Paling } \\
\text { sedikit } \\
35 \text { menit. }\end{array}$ & $\begin{array}{l}\text { Saat } \\
\text { PP: } \uparrow O\end{array}$ \\
\hline $\begin{array}{l}\text { Paternoster } \\
\text { et al., }\end{array}$ & 2020 & $\mathrm{CS}$ & 11 & P: 7 & $\begin{array}{l}62 \pm 1 \\
0\end{array}$ & - & $\begin{array}{l}\text { Tidak } \\
\text { ada }\end{array}$ & $12 \mathrm{jam}$ & $\begin{array}{l}\text { Saat } \\
\text { PP: } \uparrow O\end{array}$ \\
\hline $\begin{array}{l}\text { Winearls, } \\
\text { et al. }\end{array}$ & 2020 & $\mathrm{RS}$ & 24 & P:9 & $\begin{array}{l}62 \pm 1 \\
3\end{array}$ & - & $\begin{array}{l}\text { Tidak } \\
\text { ada }\end{array}$ & - & $\begin{array}{l}\text { Saat } \\
\text { PP: } \uparrow O\end{array}$ \\
\hline $\begin{array}{l}\text { Caputo et } \\
\text { al., }\end{array}$ & 2020 & $\mathrm{OC}$ & 50 & $P: 20$ & $\begin{array}{l}59(50 \\
-68)\end{array}$ & - & $\begin{array}{l}\text { Tidak } \\
\text { ada }\end{array}$ & - & $\begin{array}{l}\text { Saat } \\
\text { PP: } \uparrow O\end{array}$ \\
\hline $\begin{array}{l}\text { Kharat et } \\
\text { al., }\end{array}$ & 2021 & RCT & 27 & $\mathrm{P}: 10$ & $\begin{array}{l}58 \pm 1 \\
2\end{array}$ & $\begin{array}{l}28,2 \pm 4 \\
7\end{array}$ & Ada & $\begin{array}{l}12 \text { jam } \\
\text { dalam } 24 \\
\text { jam }\end{array}$ & $\begin{array}{l}\text { Saat } \\
\text { PP: -O }\end{array}$ \\
\hline $\begin{array}{l}\text { Simioli et } \\
\text { al., }\end{array}$ & 2021 & $\mathrm{CC}$ & 29 & $\mathrm{P}: 4$ & $\begin{array}{l}64 \pm 2 \\
2.5\end{array}$ & $28 \pm 2,5$ & Ada & 12 jam & $\begin{array}{l}\text { Saat } \\
\text { PP: } \uparrow O\end{array}$ \\
\hline $\begin{array}{l}\text { Sryma et } \\
\text { al., }\end{array}$ & 2021 & Q & 45 & $\mathrm{P}: 7$ & $\begin{array}{l}53.1 \pm \\
11\end{array}$ & - & Ada & $\begin{array}{l}\text { Minimal } \\
2 \\
\text { jam/sesi } \\
\text { target } 8 \\
\text { jam }\end{array}$ & $\begin{array}{l}\text { Saat } \\
\text { PP: } \uparrow O \\
\text { Setelah } \\
:-O\end{array}$ \\
\hline $\begin{array}{l}\text { Singh et } \\
\text { al., }\end{array}$ & 2020 & CS & 15 & $\mathrm{P}: 1$ & 51.5 & - & $\begin{array}{l}\text { Tidak } \\
\text { ada }\end{array}$ & $\begin{array}{l}\text { 10-12 } \\
\text { jam/hari }\end{array}$ & $\begin{array}{l}\text { Saat } \\
\text { PP: } \uparrow O\end{array}$ \\
\hline $\begin{array}{l}\text { Taboada et } \\
\text { al., }\end{array}$ & 2020 & CS & 7 & P:4 & $\begin{array}{l}67(49 \\
-77)\end{array}$ & - & $\begin{array}{l}\text { Tidak } \\
\text { ada }\end{array}$ & - & $\begin{array}{l}\text { Saat } \\
\text { PP: } \uparrow O \\
\text { Setelah } \\
:-O\end{array}$ \\
\hline $\begin{array}{l}\text { Burton- } \\
\text { Papp et al., }\end{array}$ & 2020 & RO & 20 & P:9 & $\begin{array}{l}53.4 \pm \\
8.3\end{array}$ & - & $\begin{array}{l}\text { Tidak } \\
\text { ada }\end{array}$ & - & $\begin{array}{l}\text { Saat } \\
\text { PP: } \uparrow O\end{array}$ \\
\hline Ni et al., & 2020 & PO & 52 & P: 20 & $\begin{array}{l}62 \pm \\
12\end{array}$ & - & Ada & $\begin{array}{l}4 \\
\text { jam/hari } \\
\text { selama } \\
10 \text { hari }\end{array}$ & $\begin{array}{l}\text { Saat } \\
\text { PP: } \uparrow O\end{array}$ \\
\hline $\begin{array}{l}\text { Wormser } \\
\text { et al., }\end{array}$ & 2020 & $\mathrm{RS}$ & 27 & $\mathrm{P}: 11$ & $\begin{array}{l}71(61 \\
.2- \\
80.0)\end{array}$ & $\begin{array}{l}28,1 \\
(25,4- \\
32,0)\end{array}$ & $\begin{array}{l}\text { Tidak } \\
\text { ada }\end{array}$ & $\begin{array}{l}\text { Minimal } \\
1 \text { sesi }\end{array}$ & $\begin{array}{l}\text { Saat } \\
\text { PP: } \uparrow O \\
\text { Setelah } \\
\text { PP: -O }\end{array}$ \\
\hline \multicolumn{10}{|c|}{$\begin{array}{l}\mathrm{N} \text { : jumlah sampel, RR: retrospective review, } \mathrm{PC} \text { : prospective cohort, OC: observational cohort, CS: } \\
\text { case-series, RS: retrospective study, RCT: randomized control trial, CC: case control, Q: quasi } \\
\text { experiment, RO: retrospective observational, PO: prospective observational, } \mathrm{P}: \text { perempuan, PP: posisi } \\
\text { pronasi, O: oksigenasi }\end{array}$} \\
\hline
\end{tabular}


Berdasarkan tabel 1, mayoritas sampel berjenis kelamin laki-laki dengan mean atau median usia lebih dari 50 tahun. 13 dari 14 penelitian menunjukan hasil peningkatan pada parameter oksigenasi pasien saat diberikan posisi pronasi.

Tabel. 2

Hasil Evaluasi Artikel Penelitian

\begin{tabular}{|c|c|c|c|}
\hline $\begin{array}{l}\text { Pengarang, Judul, } \\
\text { Jenis Literatur }\end{array}$ & Tahun & Tujuan & Hasil Temuan \\
\hline $\begin{array}{l}\text { Wendt et al., } \\
\text { Prone Positioning } \\
\text { of Patients with } \\
\text { Coronavirus } \\
\text { Disease } 2019 \text { Who } \\
\text { Are Nonintubated } \\
\text { in Hypoxic } \\
\text { Respiratory } \\
\text { Distress: Single- } \\
\text { Site Retrospective } \\
\text { Health Records } \\
\text { Review, } \\
\text { Retrospective } \\
\text { Chart Review }\end{array}$ & (2021) & $\begin{array}{l}\text { Untuk mengetahui } \\
\text { posisi pronasi pada } \\
\text { pasien COVID-19 } \\
\text { yang tidak } \\
\text { diintubasi dalam } \\
\text { gangguan } \\
\text { pernafasan hipoksia }\end{array}$ & $\begin{array}{l}\text { Median } \mathrm{SpO}_{2} \text { : room air vs bantuan oksigen } \\
\text { vs }+\mathrm{PP} \text { adalah } 83 \%(75 \%-86 \%) \text { vs } 90 \% \\
(89 \%-93 \%) \text { vs } 96 \%(94 \%-98 \%) \text {. Perubahan } \\
\text { median sebelum dan setelah PP signifikan } \\
\text { yaitu median } 5(4-9)(\mathrm{p}<0,001) \\
\text { Terjadi sedikit penurunan rerata HR dari } 93 \\
\text { menjadi } 88 \text { ( } \mathrm{p}<0.001) \text { dan RR rerata dari } 31 \\
\text { menjadi } 26 \mathrm{p}=0,01 \\
\text { Catatan: } \\
\text { Terdapat peningkatan bantuan oksigen pada } 7 \\
\text { pasien. Median } \mathrm{SpO}_{2} \text { pasien yang bantuan } \\
\text { oksigen tidak berubah } 4 \% \text { (3-6) dengan } \\
\text { p<0.001 } \\
\text { Durasi PP minimal } 51 \text { menit pada setiap } \\
\text { pasien. } 14(45 \%) \text { pasien diintubasi }\end{array}$ \\
\hline $\begin{array}{l}\text { Coppo et al., } \\
\text { Feasibility and } \\
\text { Physiological } \\
\text { Effects of Prone } \\
\text { Positioning in } \\
\text { Non-Intubated } \\
\text { Patients with Acute } \\
\text { Respiratory Failure } \\
\text { Due to COVID-19 } \\
\text { (PRON-COVID): } \\
\text { A Prospective } \\
\text { Cohort Study, } \\
\text { Prospective Cohort }\end{array}$ & (2020) & $\begin{array}{l}\text { Untuk menyelidiki } \\
\text { kelayakan dan efek } \\
\text { pada pertukaran gas } \\
\text { dari posisi } \\
\text { tengkurap pada } \\
\text { pasien yang sadar } \\
\text { dan tidak diintubasi } \\
\text { dengan pneumonia } \\
\text { terkait COVID-19. }\end{array}$ & $\begin{array}{l}\text { P/F sebelum dan saat PP yaitu } 180,5( \pm 76,6) \\
\text { vs } 285,5( \pm 112,9) \text {. Terdapat peningkatan } \\
\text { signifikan yaitu } 104,9 \text { (CI: } 70,9-134,0) ; \\
\text { p }<0,0001 . \mathrm{P} / \mathrm{F} 1 \text { jam setelah kembali dari PP } \\
\text { vs sebelum posisi pronasi yaitu } 192,9 \\
( \pm 100,9) \text { vs } 180,5( \pm 76,6) \text {. perubahan yaitu } \\
12,3(\mathrm{CI}:-10,9-35 \cdot 5) ; \mathrm{p}=0,29 \\
\text { Perubahan } \mathrm{SpO}_{2} \text { sebelum dan saat } 1.2(\mathrm{CI} \text { : } \\
0,8-1,7) ; \mathrm{p}<0,0001 \text {. Perubahan } \mathrm{SpO}_{2} \\
\text { sebelum dan } 1 \text { jam setelah PP: } 0,1(-1,0-0 \cdot 4) \text {; } \\
\text { p=0.35 } \\
\text { Perubahan } \mathrm{PaO}_{2} \text { sebelum dan saat PP: } 83,3 \\
(\mathrm{CI}: 56,1-110,4) ; \mathrm{p}<0,000 \text {. Perubahan PaO } \\
\text { sebelum dan } 1 \text { jam setelah PP: } 4,3(\mathrm{CI}:- \\
13,2-21,6) \\
\text { Sesak, RR tidak ada perubahan signifikan } \\
\text { sebelum, saat dan } 1 \text { jam setelah PP } \\
\text { PP layak pada } 83,9 \%(\mathrm{CI} \text { : } 71,7-92,4) \text {. Alasan } \\
\text { ketidaklayakan: ketidaknyamanan posisi, } \\
\text { batuk, tidak kooperatif, dan perburukan } \\
\text { oksigenasi }(1 \text { memerlukan intubasi) }\end{array}$ \\
\hline $\begin{array}{l}\text { Dubosh et al., } \\
\text { Early, awake } \\
\text { proning in } \\
\text { emergency } \\
\text { department patients } \\
\text { with COVID-19 } \\
\text { Observational } \\
\text { Cohort }\end{array}$ & $(2020)$ & $\begin{array}{l}\text { Untuk } \\
\text { menggambarkan } \\
\text { efek proning pada } \\
\text { oksigenasi pasien } \\
\text { COVID-19 yang } \\
\text { tidak diintubasi } \\
\text { serta mengevaluasi } \\
\text { keamanan dan hasil } \\
\text { fisiologis serta } \\
\text { klinis lainnya yang } \\
\text { terkait dengan } \\
\text { intervensi }\end{array}$ & $\begin{array}{l}\text { Median S/F } 5 \text { menit sebelum dan 5-35 menit } \\
\text { saat PP: } 295 \text { (276-350) vs } 298 \text { (263-352) } \\
\text { Median perubahan S/F yaitu } 5 \text { (0-15); CI: } \\
\text { 0,15; p=0,01 } \\
\text { Median perubahan } \mathrm{SpO}_{2} \text { : } 1 \text { (CI: 0,3); p=0,01 } \\
\text { Perubahan RR tidak signifikan denga median } \\
\text {-2 (CI: -5-3); p=0,36 } \\
\text { Durasi PP } 109 \text { (65-159) menit dengan } \\
\text { rentang 19-294 menit. } \\
\text { 23\% pasien diintubasi pada } 48 \text { jam, 9\% } \\
\text { diintubasi setelah } 48 \text { jam, } 41 \% \text { masuk ICU, } \\
9 \% \text { meninggal, dan } 91 \% \text { sembuh }\end{array}$ \\
\hline
\end{tabular}




\begin{tabular}{|c|c|c|c|}
\hline $\begin{array}{l}\text { Paternoster et al., } \\
\text { Awake Pronation } \\
\text { with Helmet } \\
\text { Continuous } \\
\text { Positive Airway } \\
\text { Pressure for } \\
\text { COVID-19 Acute } \\
\text { Respiratory } \\
\text { Distress Syndrome } \\
\text { Patients Outside } \\
\text { the ICU: A Case } \\
\text { Series, } \\
\text { Case-Series }\end{array}$ & (2020) & $\begin{array}{l}\text { Untuk mengetahui } \\
\text { posisi pronasi untuk } \\
\text { pasien dengan } \\
\text { sindrom pernafasan } \\
\text { akut COVID-19 di } \\
\text { luar ICU }\end{array}$ & $\begin{array}{l}\text { Terjadi peningkatan rerata } \mathrm{P} / \mathrm{F}, \mathrm{SpO}_{2} \text { dan } \\
\text { penurunan RR. } \\
\text { Rerata } \mathrm{SpO}_{2} \text { sebelum dan setelah } 72 \text { jam PP: } \\
90 \%( \pm 2,3) \text { vs } 97 \%( \pm 3,1) ; \mathrm{p}<0,001 \\
\text { Rerata } \mathrm{P} / \mathrm{F} \text { sebelum dan setelah } 72 \text { jam PP: } \\
107,5( \pm 20,8) \text { vs } 244,4( \pm 106,2) ; \mathrm{p}<0,001 \\
\text { Rerata RR sebelum dan setelah } 72 \text { jam } \mathrm{PP} \text { : } \\
27( \pm 4,3) \text { vs } 20( \pm 4,3) \text {; }=0,004 \\
\text { Tidak ada perubahan signifikan pada } \mathrm{PaCO}_{2} \\
\text { Rerata durasi siklus PP: } 13 \pm 1,2 \text { jam } \\
\text { Follow up } 28 \text { hari, } 82 \% \text { pasien sembuh, } 3 \\
\text { pasien diintubasi }(2 \text { diantaranya meninggal })\end{array}$ \\
\hline $\begin{array}{l}\text { Winearls et al., } \\
\text { Early Conscious } \\
\text { Prone Positioning } \\
\text { in Patients with } \\
\text { COVID-19 } \\
\text { Receiving } \\
\text { Continuous } \\
\text { Positive Airway } \\
\text { Pressure: A } \\
\text { Retrospective } \\
\text { Analysis, } \\
\text { Retrospective } \\
\text { Study }\end{array}$ & (2020) & $\begin{array}{l}\text { Mengetahui Posisi } \\
\text { Prone pada pasien } \\
\text { dengan COVID-19 } \\
\text { yang menerima } \\
\text { tekanan saluran } \\
\text { udara positif } \\
\text { berkelanjutan }\end{array}$ & $\begin{array}{l}\text { Rerata } \mathrm{SpO}_{2} \text { sebelum, saat CPAP dan setelah } \\
1 \text { jam CPAP+PP: } 94 \pm 3 \% \text { vs } 95 \% \pm 2 \% \text { vs } \\
96 \% \pm 2 \% \text { ( }=0,23 \text { pada CPAP, }<<0,005 \text { pada } \\
\text { CPAP+PP } \\
\text { Rerata P/F sebelum, saat CPAP dan setelah } 1 \\
\text { jam CPAP+PP: } 143 \pm 73 \text { vs } 201 \pm 70 \text { vs } \\
252 \pm 87 \text { (p=0,34 pada CPAP, } \mathrm{p}<0,01 \text { pada } \\
\text { CPAP+PP) } \\
\text { Rerata indeks ROX sebelum, saat CPAP dan } \\
\text { setelah } 1 \text { jam CPAP+PP: } 7.0 \pm 2.5 \text { vs vs } \\
8.9 \pm 3.2 \text { vs } 11.4 \pm 3.7 \text { ( }=0,31 \text { pada CPAP, } \\
\text { p<0,0001 pada CPAP+PP) } \\
\text { Tidak ada perubahan signifikan pada RR } \\
\text { (p=0,24). } 2 \text { pasien tidak mentoleransi PP } \\
\text { karena perburukan oksigenasi dan nyeri } \\
\text { Rerata durasi PP: } 8 \pm 5 \text { jam/24 jam pertama, } \\
\text { total rerata durasi PP: } 10 \pm 5 \text { hari. } 12 \text { pasien } \\
\text { full PP dan } 10 \text { pasien semipronasi/lateral } \\
\text { Tidak ada perbedaan signifikan antara pasien } \\
\text { full PP dengan semi-pronasi. }\end{array}$ \\
\hline $\begin{array}{l}\text { Caputo et al., } \\
\text { Early Self-Proning } \\
\text { in Awake, Non- } \\
\text { intubated Patients } \\
\text { in the Emergency } \\
\text { Department: A } \\
\text { Single ED's } \\
\text { Experience During } \\
\text { the COVID-19 } \\
\text { Pandemic, } \\
\text { Observational } \\
\text { Cohort }\end{array}$ & (2020) & $\begin{array}{l}\text { menggambarkan } \\
\text { penggunaan } \\
\text { proning dini pada } \\
\text { pasien yang sadar } \\
\text { dan tidak diintubasi } \\
\text { di unit gawat } \\
\text { darurat (ED) selama } \\
\text { pandemi COVID- } \\
19\end{array}$ & $\begin{array}{l}\text { Median } \mathrm{SpO}_{2} \text { awal, setelah bantuan oksigen, } \\
\text { dan tambahan PP: } 80 \%(69-85) \text { vs } 84 \% \text { (75- } \\
90) \text { vs } 94 \% \text { (90-95) } \\
\text { Perbandingan pre dan post PP didapatkan } \\
\text { hasil signifikan, p=0,001 } \\
24 \% \text { pasien memerlukan intubasi endotrakeal } \\
\text { sebelum } 24 \text { jam PP }\end{array}$ \\
\hline $\begin{array}{l}\text { Kharat et al., } \\
\text { Self-Proning in } \\
\text { COVID-19 } \\
\text { Patients on Low- } \\
\text { Flow Oxygen } \\
\text { Therapy: A Cluster } \\
\text { Randomised } \\
\text { Controlled Trial, } \\
R C T\end{array}$ & (2021) & $\begin{array}{l}\text { Mengetahui posisi } \\
\text { proneing sebagai } \\
\text { pelengkap terapi } \\
\text { oksigen untuk } \\
\text { mengobati } \\
\text { hipoksemia pada } \\
\text { penyakit } \\
\text { pneumonia } \\
\text { COVID-19 }\end{array}$ & $\begin{array}{l}\text { Median kebuhan oksigen sebelum PP } 2,5 \\
(2.0-3.0) \text { lpm pada kelompok perlakuan vs } 2 \\
(1.0-3.0) \text { lpm pada kelompok kontrol. Setelah } \\
24 \text { jam PP menjadi } 1(0.1-2.9) \text { lpm vs } 2(0.5- \\
\text { 3.0) lpm. } \\
\text { Median S/F sebelum PP } 318(284-341) \\
\text { kelompok perlakuan vs } 336(303-388) \\
\text { kelompok kontrol. Setelah PP menjadi } 390 \\
\text { (303-432) vs } 336(294-422) \\
\text { Perbedaan kebutuhan oksigen antara dua } \\
\text { kelompok: }-1(\mathrm{CI}:-2.75-2) ; \mathrm{p}=0,507 \\
\text { Perbedaan S/F antara dua kelompok: } 54 \\
(-91.6-133.0) ; \mathrm{p}=0,633\end{array}$ \\
\hline
\end{tabular}




\begin{tabular}{|c|c|}
\hline $\begin{array}{l}\text { Simioli et al., } \\
\text { Early Prone } \\
\text { Positioning and } \\
\text { Non-Invasive } \\
\text { Ventilation in a } \\
\text { Critical COVID-19 } \\
\text { Subset. A Single } \\
\text { Centre Experience } \\
\text { in Southern Italy, } \\
\text { Case-Control }\end{array}$ & $\begin{array}{l}\text { menyelidiki efek } \\
\text { dan kelayakan PP } \\
\text { pada penyakit } \\
\text { coronavirus 2019 } \\
\text { (COVID-19) terkait } \\
\text { pasien sadar dengan } \\
\text { ARDS dalam } \\
\text { pengaturan } \\
\text { perawatan } \\
\text { subintensif }\end{array}$ \\
\hline
\end{tabular}
Mean P/F awal adalah $96.5( \pm 35)$ pada kelompok PP dan $95( \pm 92)$ pada kelompok kontrol. Setelah pemberian NIV, mean P/F adalah 175,5 $( \pm 94)$ pada kelompok PP dan 175 ( \pm 136$)$ pada kelompok kontrol. Pada pemberian NIV+PP, P/F menjadi $288( \pm 80)$ pada kelompok PP dan $202( \pm 122)$ pada kelompok kontrol.
Perbedaan rerata P/F awal dan setelah NIV antara dua kelompok tidak signifikan $(\mathrm{p}=0,77$ vs $\mathrm{p}=0,53$ )

Perbedan rerata $\mathrm{P} / \mathrm{F}$ setelah NIV+PP antara dua kelompok adalah 115.0; $\mathrm{p}=0.0002$ Durasi gagal napas kelompok PP dan kontrol signifikan berbeda: $14( \pm 7.5)$ hari vs $21( \pm 6)$ hari (perbedaan rerata, $-7.82 ; \mathrm{p}=0.002$ ) Angka intubasi pada kelompok PP adalah 5,5\%. Angka intubasi pada kelompok kontrol adalah $18 \%$ dengan kematian $27 \%$.

Sryma et al., Effect of Proning in Patients with COVID-19 Acute Hypoxemic Respiratory Failure Receiving Noninvasive Oxygen Therapy, Kuasi Eksperimen

\section{(2021) Untuk mengetahui} apakah posisi rawan terjaga (PP) dapat meningkatkan oksigenasi dan mencegah intubasi ketika digunakan lebih awal
Tingkat intubasi pada kelompok kontrol lebih tinggi dibanding kelompok perlakuan $(33,3 \%$ vs $6,7 \%$ )

Rerata $\mathrm{SpO}_{2}$ awal adalah $92,4 \%( \pm 2.8)$ pada kelompok perlakuan dan $94,1 \%( \pm 4,3)$ pada kelompok kontrol; $\mathrm{p}=0,11.30$ menit setelah PP menjadi 94,8\% ( \pm 1.7$)$ vs 95,5\% ( \pm 2.5$)$; $\mathrm{p}=0.26$. 12 jam setelah PP menjadi $95,3 \%$ $( \pm 2.3)$ vs $93,9 \%( \pm 8.1)$; $\mathrm{p}=0,4$.

Rerata Indeks ROX kelompok perlakuan dan kontrol awal: 8,5 ( \pm 2.3$)$ vs 7,3 ( \pm 2.6$)$; $\mathrm{p}<0.001 .30$ menit setelah PP $10,7( \pm 3.8)$ vs $6,7$ ( \pm 2.6$) ; \mathrm{p}<0.001 .12$ jam PP; $12,4( \pm 4.0)$ vs $6,4( \pm 3.0) ; p<0.001$

Rerata RR antar kelompok awal $\mathrm{p}=0.09,30$ menit PP $\mathrm{p}=0.67,12$ jam PP $\mathrm{p}=0,004$

Kematian pada kelompok PP 6,7\% dan kelompok kontrol 26,7\%

Median durasi PP pada 1 hari pertama: 7,5 jam (4-12)

\begin{tabular}{|c|c|c|}
\hline $\begin{array}{l}\text { Singh et al., } \\
\text { Awake Prone } \\
\text { Positioning in }\end{array}$ & (2020) & $\begin{array}{l}\text { Untuk mengetahui } \\
\text { posisi proning pada } \\
\text { pasien COVID-19 }\end{array}$ \\
\hline
\end{tabular}

COVID-19

Patients,

Case-Series Rerata P/F posisi supinasi vs posisi pronasi: 3 hari pertama $98.8 \pm 29.7$ vs $136.6 \pm 38.8$; hari ke-4-6 adalah $142,4 \pm 40.9$ vs $173,9 \pm 46.6$; hari ke- $7-10$ adalah $178,3 \pm 38.3$ vs $214,8 \pm 44.2$; hari ke-11 adalah $210,3 \pm 32.5$ vs 218,6 . Secara berurutan nilai $\mathrm{p}(0.050,0.033$, dan 0.692). Hanya 2 pasien yang diintubasi

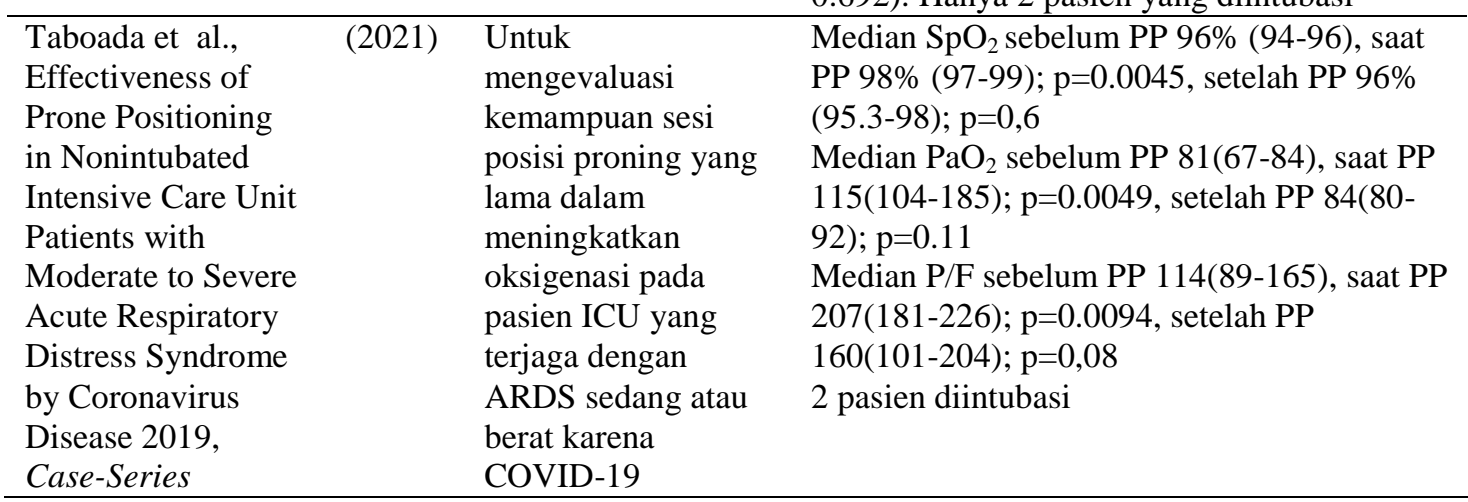




\begin{tabular}{|c|c|}
\hline $\begin{array}{l}\text { Burton-Papp et al., (2020) } \\
\text { Conscious prone } \\
\text { positioning during } \\
\text { non-invasive } \\
\text { ventilation in } \\
\text { COVID-19 } \\
\text { patients: } \\
\text { experience from a } \\
\text { single centre, } \\
\text { Retrospective } \\
\text { Observational }\end{array}$ & $\begin{array}{l}\text { Mengetahui posisi } \\
\text { prone selama } \\
\text { ventilasi non- } \\
\text { invasif pada pasien } \\
\text { COVID-19 }\end{array}$ \\
\hline
\end{tabular}

\author{
Secara keseluruhan rerata peningkatan $\mathrm{P} / \mathrm{F}$ \\ pada 20 pasien adalah $28,7 \mathrm{mmHg}(95 \% \mathrm{CI}$ : \\ 18,7-38,6 mmHg, $\mathrm{p}<0.01)$ tanpa adanya \\ perubahan RR dan HR \\ $35 \%$ pasien akhirnya diintubasi \\ $65 \%$ pasien yang berhasil NIV+PP \\ mengalami peningkatan P/F lebih besar: 40,8 \\ $\mathrm{mmHg}$ (CI: 28,8-52,7 mmHg, p<0.01) \\ Pasien yang diintubasi tidak memiliki \\ peningkatan signifikan $\mathrm{P} / \mathrm{F}:+5,06 \mathrm{mmHg}$ \\ (95\% CI -9,5-19,7 mmHg, $\mathrm{p}=0.48$ )
} Lama rawat ICU NIV+PP, NIV+IMV: 5 (5.0) vs 14 (17.0) Lama rawat RS NIV+PP, NIV+IMV: 11 (9) vs $28(5.5)$

Pindah ke pusat SARF NIV+PP, NIV+IMV: 0 vs 2

Semua pasien sembuh/tidak ada kematian

\begin{tabular}{|c|c|}
\hline $\begin{array}{l}\text { Ni et al., } \\
\text { The Efficacy of } \\
\text { Early Prone or } \\
\text { Lateral Positioning } \\
\text { in Patients with } \\
\text { Severe COVID-19: } \\
\text { A Single-Center }\end{array}$ & $\begin{array}{l}\text { Untuk menyelidiki } \\
\text { kemanjuran } \\
\text { intervensi posisi } \\
\text { awal pada pasien } \\
\text { berventilasi non- } \\
\text { invasif dengan } \\
\text { COVID-19 parah }\end{array}$ \\
\hline
\end{tabular}
Perbedaan rata-rata S/F mulai meningkat secara signifikan sejak hari ke-4 dengan nilai kumulatif 409 (95\% CI: 86-733) setelah menerima intervensi posisi pronasi selama 7 hari

Terjadi peningkatan indeks ROX sejak hari ke-3: kumulatif 26 (95\% CI: 9-43); Terjadi penurunan skala Borg sejak hari ke-3:

Prospective

Cohort,

Prospective

Observational Cohort kumulatif -9 (95\% CI: -15 - -3); PP secara signifikan meningkatkan oksigenasi dan menurunkan sesak dibanding perawatan biasa, lesi paru secara signifikan menurun pada kedua kelompok, Proporsi EWS tinggi (skor $\geq 7$ ) secara signifikan lebih sedikit pada kelompok PP; Ada kecenderungan waktu peningkatan hasil klinis yang lebih pendek pada kelompok PP dibanding kontrol, namun secara statistik tidak signifikan $(\mathrm{p}=0.138)$; Tidak ada perbedaan lama rawat antara dua kelompok; Tidak ada perbedaan yang signifikan pada angka intubasi (PP:0, kontrol: 1 kejadian)

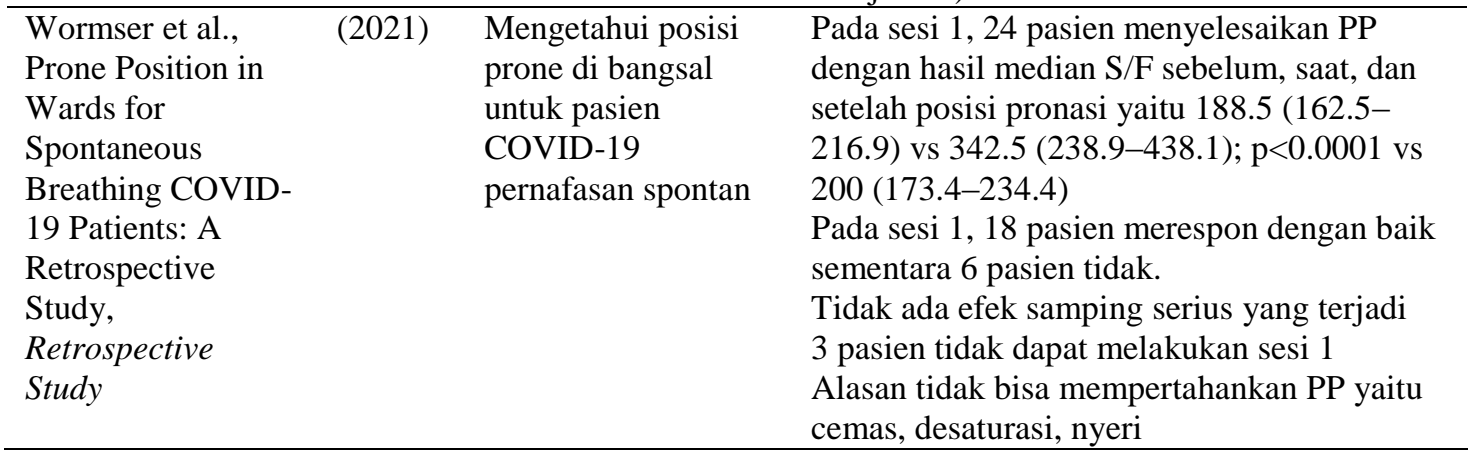

Berdasarkan tabel 2 menunjukkan bahwa empat belas (14) artikel yang memenuhi kriteria telah dianalisis. Total sampel dari 14 artikel yang dianalisis adalah 416 dimana $69,7 \%$ berjenis kelamin laki-laki dan $30,3 \%$ berjenis kelamin perempuan. Rata- rata atau median usia dari semua penelitian adalah di atas 50 tahun. Sedangkan untuk IMT, hanya 7 dari 14 penelitian yang melaporkannya dan semuanya menunjukan hasil rata- 
rata atau median diatas nilai normal menurut WHO $(>22,9)$. Durasi (lama) pemberian posisi pronasi disebutkan pada 7 dari 14 penelitian, dengan durasi paling pendek yaitu 35 menit dalam satu hari dan durasi paling panjang adalah 12 jam per hari. Satu penelitian mengamati pemberian posisi pronasi selama 10 hari sedangkan yang lain tidak mengamati. Sementara itu, untuk metode pemberian bantuan terapi oksigenasi antara lain nasal kanul, helm CPAP, masker CPAP, masker sederhana, masker reservoir, masker venturi, non-rebreathing mask (NRM), HFNC, serta BiPAP.

Hasil utama yang dianalisis yaitu oksigenasi pasien yang meliputi salah satu atau lebih dari parameter berikut: $\mathrm{SpO}_{2}, \mathrm{PaO}_{2} / \mathrm{FiO}_{2}, \quad \mathrm{SpO}_{2} / \mathrm{FiO}_{2}$, dan indeks ROX $\left(\mathrm{SpO}_{2} / \mathrm{FiO}_{2} / \mathrm{RR}\right)$. Sebagian besar penelitian (92\%) menunjukan adanya peningkatan oksigenasi saat dilakukan posisi pronasi. Sementara itu pengamatan setelah pemberian posisi pronasi (kembali ke posisi supinasi) hanya dilakukan pada 4 penelitian dengan hasil yang menunjukan tidak ada perubahan oksigenasi dibandingkan sebelum posisi pronasi.

Hasil lain yang diamati adalah tingkat intubasi pasien dan didapat sebanyak 47 dari 338 pasien $(13,9 \%)$ yang mendapat posisi pronasi pada akhirnya diintubasi. Selain itu, pada dua dari 14 penelitian terdapat pemberian sedasi ringan dexmedetomidine pada pasien untuk meningkatkan toleransi dan komplians pasien terhadap posisi pronasi.

\section{PEMBAHASAN}

Tenaga kesehatan menghadapi tantangan yang cukup besar dalam mengatasi pandemi COVID-19 saat ini. Berbagai intervensi dikembangkan dan diimplementasikan pada pasien COVID-19 untuk meningkatkan hasil klinis pasien. Salah satu intervensi yang baru-baru ini diteliti adalah posisi pronasi pada pasien COVID-19 sadar atau yang tidak terintubasi. Posisi pronasi merupakan salah satu intervensi yang sudah banyak dilakukan pada pasien ARDS dengan ventilasi mekanis. Terdapat beberapa bukti yang cukup meyakinkan tentang manfaat posisi pronasi pada pasien ARDS dengan ventilasi mekanis (Liu et al., 2021; Poon et al., 2021). Berdasarkan panduan WHO, posisi pronasi adalah rekomendasi tambahan dalam perawatan pasien COVID-19 yang mengalami sakit berat dan memerlukan bantuan oksigen (termasuk high flow nasal cannula) atau ventilasi non-invasif. Namun, intervensi ini disarankan untuk dilakukan sesuai kondisi/dengan syarat tertentu (WHO, 2021). Hal ini berkaitan dengan bukti yang masih sangat terbatas (Anand et al., 2021; WHO, 2021).

Tinjauan sistematis ini mengevaluasi intervensi posisi pronasi terhadap oksigenasi pasien COVID-19 sadar yang mendapat terapi oksigen non-invasif. Berdasarkan tinjauan yang dilakukan pada semua artikel, ditemukan bahwa terapi oksigen yang didapat pasien bervariasi. Hal ini mungkin karena kebutuhan oksigen setiap pasien berbeda-beda bergantung pada keparahan penyakit (WHO, 2021). Di lapangan juga sering kita temui bahwa kebutuhan oksigen berbeda-beda pada setiap pasien. Adapun metode pemberian bantuan oksigen yang diidentifikasi pada tinjauan ini antara lain nasal kanul, helm CPAP, masker CPAP, masker sederhana, masker reservoir, masker venturi, non-rebreathing mask (NRM), HFNC, serta BiPAP. Analisis dilakukan pada 14 artikel penelitian dengan total sampel 416. Tiga belas dari 14 artikel penelitian (92\%) menunjukan adanya peningkatan oksigenasi pada pasien saat posisi pronasi dimplementasikan. Namun, satu artikel RCT menunjukan hasil oksigenasi yang tidak bermakna secara statistik pada pasien COVID-19. Sampel yang diteliti adalah pasien COVID-19 yang mendapat terapi oksigen aliran rendah (1-6 liter per menit melalui 
nasal kanula) dan oksigenasi sebelum implementasi posisi pronasi cukup baik (S/F>300) pada kedua kelompok (Kharat et al., 2021).

Oksigenasi diukur dengan salah satu atau lebih dari parameter $\mathrm{SpO}_{2}, \mathrm{PaO}_{2} / \mathrm{FiO}_{2}$, $\mathrm{SpO}_{2} / \mathrm{FiO}_{2}$, dan indeks ROX. $\mathrm{SpO}_{2}$ dan $\mathrm{PaO}_{2} / \mathrm{FiO}_{2}$ dievaluasi pada 7 penelitian. $\mathrm{SpO} 2 / \mathrm{FiO} 2$ dan indeks ROX dievaluasi dalam 3 penelitian. Meskipun sebagian besar penelitian menunjukan hasil yang bermakna pada peningkatan oksigenasi saat posisi pronasi, terdapat 4 penelitian yang mengevaluasi oksigenasi setelah posisi pronasi (pasien kembali ke posisi supinasi) dengan hasil yang menunjukan tidak ada peningkatan bermakna oksigenasi dari sebelum posisi pronasi. Hal ini mungkin berkaitan dengan efek fisiologis posisi pronasi pada pasien yang hanya terjadi ketika posisi tersebut diimplementasikan. Pada posisi pronasi, terjadi peningkatan kecocokan ventilasi-perfusi. Bagian dorsal paru-paru (yang secara anatomis memiliki jumlah unit alveolar lebih banyak) terbuka kembali karena tidak terkompresi oleh mediastinum atau rongga perut yang pada akhirnya mengakibatkan peningkatan pertukaran gas di alveolar-kapiler paru (Bamford et al., 2020). Saat pasien kembali ke posisi supinasi, maka secara fisiologis efek ini akan kembali seperti semula sehingga tidak ada pningkatan oksigenasi jika dibandingkan dengan sebelum posisi pronasi.

Selain oksigenasi, hampir semua penelitian mengamati tingkat intubasi pada pasien yang mendapat posisi pronasi. Berdasarkan hasil evaluasi terhadap 14 artikel penelitian, sebanyak 47 dari 338 pasien (13,9\%) yang mendapat perlakuan posisi pronasi pada akhirnya diintubasi. Jangka waktu intubasi sejak posisi pronasi bervariasi mulai dari 24 jam hingga 28 dari setelah posisi pronasi. Angka tingkat intubasi ini lebih rendah dibanding dengan yang dilaporkan tinjauan sistematis lain yang sebesar $23,8 \%$ (Anand et al., 2021). Akan tetapi angka ini tidak pasti karena kebutuhan ventilasi mekanis pada pasien berbeda-beda (dapat menurun atau meningkat), tergantung pada keparahan penyakit (Tobin et al., 2020).

Durasi posisi pronasi yang diberikan kepada pasien sangat bervariasi. Berdasarkan hasil sintesis semua artikel (tabel 1) dapat dilihat bahwa posisi pronasi dilakukan paling sedikit selama 35 menit dalam satu hari dan paling lama 12 jam dalam satu hari. Sebagian besar penelitian tidak menjelaskan secara spesifik bagaimana posisi pronasi diberikan kepada pasien. Satu penelitian memberikan posisi pronasi satu jam setelah pasien makan untuk mencegah efek samping atau komplikasi gastrointestinal (Singh et al., 2020). Dua penelitian memberikan prosedur posisi pronasi dengan posisi tempat tidur reverse Trendelenburg (Sryma et al., 2021; Wendt et al., 2021). Hal ini berbeda dengan panduan dari Intensive Care Society (ICS) tentang posisi pronasi pada pasien COVID-19 dalam kondisi sadar dimana posisi pronasi diberikan pada posisi tempat tidur datar/rata (Bamford et al., 2020).

Tiga penelitian melakukan perubahan posisi (diselingi posisi lain) pada masingmasing 2, 4, dan 12 jam (Kharat et al., 2021; Paternoster et al., 2020; Simioli et al., 2021). Perubahan posisi dilakukan untuk mencegah luka tekan dan nyeri sendi (Simioli et al., 2021). Hal ini sesuai dengan panduan dari ICS bahwa posisi pasien harus diubah setiap 0,5-2 jam atau lebih jika memungkinkan. Perubahan posisi yang direkomendasikan meliputi 30 menit hingga 2 jam dalam posisi berikut: pronasi sepenuhnya dengan tempat tidur rata; lateral kanan dengan tempat tidur rata; duduk tegak 30-60 '; lateral kiri dengan tempat tidur rata; kembali ke posisi supinasi, kemudian diulangi lagi dari posisi pronasi (Bamford et al., 2020). Perubahan posisi dapat dilakukan mandiri oleh pasien jika memungkinkan. Jika tidak memungkinkan, perubahan posisi dibantu oleh tenaga kesehatan yang sudah terlatih. 
Sebagian besar penelitian menyebutkan bahwa posisi pronasi hanya dilakukan pada pasien yang dapat mentoleransi posisi. Apabila pasien tidak mentoleransi maka posisi dapat dihentikan. Hal ini sesuai dengan literatur bahwa posisi harus dihentikan jika pasien tidak menunjukan perbaikan dan tidak dapat mentoleransi perubahan posisi, frekuensi pernapasan $\geq 35$ atau ada bukti kelelahan dan/atau penggunaan otot bantu pernapasan. Pasien yang tidak memungkinkan untuk melakukan posisi pronasi harus dirawat dalam posisi tegak $30-60^{\circ}$ (Bamford et al., 2020). Selain itu, literatur tentang posisi pronasi pada pasien ARDS menyebutkan bahwa pasien harus dalam kondisi hemodinamik stabil dan MAP $\geq 65 \mathrm{mmHg}$ pada saat implementasi posisi (Guerin et al., 2020). Terdapat kontraindikasi mutlak dan relatif yang perlu dipertimbangkan dalam mengimplementasikan posisi pronasi. Kontraindikasi mutlak yaitu distres pernapasan (laju pernapasan $\geq 35, \mathrm{PaCO}_{2} \geq 65$, dan/atau penggunaan otot bantu napas), kebutuhan segera untuk intubasi, ketidakstabilan hemodinamik (tekanan darah sistolik $<90 \mathrm{mmHg}$ ) atau aritmia, agitasi atau perubahan status mental, kondisi tulang belakang tidak stabil/cedera toraks/pembedahan abdomen tidak lama ini. Sedangkan kontraindikasi relatif termasuk cedera wajah, masalah neurologis, obesitas morbid, kehamilan (trimester 2/3) dan luka tekan/ulkus (Bamford et al., 2020).

Pada tinjauan sistematis ini, terdapat beberapa kondisi yang diidentifikasi terkait ketidakmampuan pasien melanjutkan posisi pronasi (mentoleransi posisi) antara lain adanya ketidaknyamanan posisi, pasien tidak kooperatif, terjadi perburukan oksigenasi, desaturasi, nyeri, serta kecemasan pada pasien (Coppo et al., 2020; Winearls et al., 2020; Wormser et al., 2021). Semua pasien harus dipantau secara ketat untuk hemodinamik, ketidaknyamanan, serta segala perburukan yang mungkin terjadi pada pasien saat implementasi posisi pronasi. Penggunaan obat sedatif atau ansiolitik dapat meningkatkan kepatuhan terhadap proning, tetapi harus digunakan hanya jika bangsal atau ruang perawatan dilengkapi dengan alat pemantauan ketat status hemodinamik dan oksigenasi pasien (Anand et al., 2021).

Pada dua penelitian, terdapat pemberian sedasi ringan dexmedetomidine pada 63,6\% Paternoster et al., (2020) dan 100\% Taboada et al., (2021) pasien untuk meningkatkan toleransi dan komplians pasien terhadap posisi pronasi. Dosis dexmedetomidine yang diberikan masing-masing adalah $0,7-1,2 \mathrm{mcg} / \mathrm{kgBB} / \mathrm{jam}$ dan $0,2-0,8 \mathrm{mcg} / \mathrm{kgBB} / \mathrm{jam}$. Dexmedetomidine merupakan agonist 2-adrenoseptor dengan efek sedatif, ansiolitik, hipnotik, analgesik, dan simpatolitik.

Terdapat beberapa keterbatasan dalam penelitian ini. Pertama, sebagian besar penelitian adalah case-series, kohort, dan retrospektif observasional. Terdapat satu penelitian RCT namun dengan hasil yang tidak bermakna. Kedua, semua penelitian yang diidentifikasi memiliki ukuran sampel yang sangat kecil. Ketiga, mayoritas penelitian tidak menggunakan kelompok kontrol/pembanding. Hanya ada 4 dari 14 penelitian yang menggunakan kelompok kontrol. Keempat, sebagian besar penelitian tidak mengidentifikasi efek dalam jangka waktu yang lebih panjang dari aplikasi posisi pronasi. Terakhir, durasi posisi pronasi dan parameter penilaian oksigenasi yang masih sangat bervariasi. Hal ini menyebabkan sulit untuk memerkirakan efek posisi pronasi dengan tepat. Namun, disamping beberapa kekurangan tersebut, sebagian penelitian menujukan bahwa posisi pronasi merupakan intervensi yang layak dan aman diimplementasikan pada pasien COVID-19 dengan penurunan oksigenasi dan mendapat terapi oksigen tambahan non-invasif. Efek samping yang dilaporkan sedikit dan tidak terlalu berat. 


\section{SIMPULAN}

Posisi pronasi merupakan intervensi yang layak, aman, tidak memerlukan banyak biaya dan mudah diimplementasikan pada pasien COVID-19 dengan sedikit efek samping. Secara keseluruhan, posisi pronasi mungkin dapat diimplementasikan pada pasien COVID19 tertentu dengan pemantauan secara ketat oleh tenaga kesehatan terlatih dan berpengalaman.

\section{SARAN}

Hampir semua bukti pada tinjauan ini memiliki kualitas rendah pada tingkat kepastian mengenai manfaat bersih dari posisi pronasi. Oleh karena itu, penulis tidak dapat merekomendasikan atau tidak merekomendasikan implementasi posisi pronasi pada pasien COVID-19 sadar yang mendapat terapi oksigen non-invasif. Tinjauan ini tidak dapat memberikan pedoman pasti dalam menerapkan praktik keperawatan berbasis bukti. Peneliti selanjutnya diharapkan dapat melakukan tinjauan sistematis terhadap penelitian-penelitian RCT untuk memperkuat bukti yang ada.

\section{DAFTAR PUSTAKA}

Anand, S., Baishya, M., Singh, A., \& Khanna, P. (2021). Effect of Awake Prone Positioning in COVID-19 Patients- A Systematic Review. Trends in Anaesthesia and Critical Care, 36, 17-22. https://doi.org/10.1016/j.tacc.2020.09.008

Bamford, P., Bentley, A., Dean, J., Whitmore, D., \& Wilson-Baig, N. (2020). ICS Guidance for Prone Positioning of the Conscious COVID Patient 2020. Intensive Care Society

Chad, T., \& Sampson, C. (2020). Prone Positioning in Conscious Patients on Medical Wards: A Review of the Evidence and Its Relevance to Patients with COVID-19 Infection. Clin Med (Lond), 20(4), e97-e103. https://doi.org/10.7861/clinmed.2020-0179

Coppo, A., Bellani, G., Winterton, D., Di-Pierro, M., Soria, A., Faverio, P., Cairo, M., Mori, S., Messinesi, G., Contro, E., Bonfanti, P., Benini, A., Valsecchi, M. G., Antolini, L., \& Foti, G. (2020). Feasibility and Physiological Effects of Prone Positioning in Non-Intubated Patients with Acute Respiratory Failure Due to COVID-19 (PRON-COVID): A Prospective Cohort Study. The Lancet Respiratory Medicine, 8(8), 765-774. https://doi.org/10.1016/s22132600(20)30268-x

Esakandari, H., Nabi-Afjadi, M., Fakkari-Afjadi, J., Farahmandian, N., Miresmaeili, S. M., \& Bahreini, E. (2020). A Comprehensive Review of COVID-19 Characteristics. Biol Proced Online, 22, 19. https://doi.org/10.1186/s12575-02000128-2

Guerin, C., Albert, R. K., Beitler, J., Gattinoni, L., Jaber, S., Marini, J. J., Munshi, L., Papazian, L., Pesenti, A., Vieillard-Baron, A., \& Mancebo, J. (2020). Prone Position in ARDS Patients: Why, When, How and for Whom. Intensive Care Med, 46(12), 2385-2396. https://doi.org/10.1007/s00134-020-06306-w

Ji, Y., Ma, Z., Peppelenbosch, M. P., \& Pan, Q. (2020). Potential Association Between COVID-19 Mortality and Health-Care Resource Availability. The Lancet Global Health, 8(4). https://doi.org/10.1016/s2214-109x(20)30068-1 
Kharat, A., Dupuis-Lozeron, E., Cantero, C., Marti, C., Grosgurin, O., Lolachi, S., Lador, F., Plojoux, J., Janssens, J. P., Soccal, P. M., \& Adler, D. (2021). SelfProning in COVID-19 Patients on Low-Flow Oxygen Therapy: A Cluster Randomised Controlled Trial. ERJ Open Res, 7(1). https://doi.org/10.1183/23120541.00692-2020

Liu, C., Chen, Y., Chen, Y., Chen, B., Xie, G., \& Chen, Y. (2021). Effects of Prone Positioning during Extracorporeal Membrane Oxygenation for Refractory Respiratory Failure: A Systematic Review. SN Compr Clin Med, 1-7. https://doi.org/10.1007/s42399-021-01008-w

Lovato, A., De-Filippis, C., \& Marioni, G. (2020). Upper Airway Symptoms in Coronavirus Disease 2019 (COVID-19). Am J Otolaryngol, 41(3), 102474. https://doi.org/10.1016/j.amjoto.2020.102474

Ni, Z., Wang, K., Wang, T., Ni, Y., Huang, W., Zhu, P., \& Liu, D. (2020). The Efficacy of Early Prone or Lateral Positioning in Patients with Severe COVID-19: A Single-Center Prospective Cohort. Precision Clinical Medicine, 3(4), 260-271. doi:10.1093/pcmedi/pbaa034

Parasher, A. (2020). COVID-19: Current Understanding of Its Pathophysiology, Clinical Presentation and Treatment. Postgrad Med J. https://doi.org/10.1136/postgradmedj-2020-138577

Paternoster, G., Sartini, C., Pennacchio, E., Lisanti, F., Landoni, G., \& Cabrini, L. (2020). Awake Pronation with Helmet Continuous Positive Airway Pressure for COVID-19 Acute Respiratory Distress Syndrome Patients Outside the ICU: A Case Series. Med Intensiva (Engl Ed). https://doi.org/10.1016/j.medin.2020.08.008

Peng, P. W. H., Ho, P. L., \& Hota, S. S. (2020). Outbreak of a New Coronavirus: What Anaesthetists Should Know. Br J Anaesth, 124(5), 497-501. https://doi.org/10.1016/j.bja.2020.02.008

Poon, W. H., Ramanathan, K., Ling, R. R., Yang, I. X., Tan, C. S., Schmidt, M., \& Shekar, K. (2021). Prone Positioning during Venovenous Extracorporeal Membrane Oxygenation for Acute Respiratory Distress Syndrome: A Systematic Review and Meta-Analysis. Crit Care, 25(1), 292. https://doi.org/10.1186/s13054-021-03723-1

Simioli, F., Annunziata, A., Langella, G., Martino, M., Musella, S., \& Fiorentino, G. (2021). Early Prone Positioning and Non-Invasive Ventilation in a Critical COVID-19 Subset. A Single Centre Experience in Southern Italy. Turk Thorac J, 22(1), 57-61. https://doi.org/10.5152/TurkThoracJ.2021.20158

Singh, P., Jain, P., \& Deewan, H. (2020). Awake Prone Positioning in COVID-19 Patients. Indian J Crit Care Med, 24(10), 914-918. https://doi.org/10.5005/jpjournals-10071-23546

Sryma, P. B., Mittal, S., Mohan, A., Madan, K., Tiwari, P., Bhatnagar, S., Trikha, A., Dosi, R., Bhopale, S., Viswanath, R., Hadda, V., Guleria, R., \& Baldwa, B. (2021). Effect of Proning in Patients with COVID-19 Acute Hypoxemic Respiratory Failure Receiving Noninvasive Oxygen Therapy. Lung India, 38(Supplement), S6-S10. https://doi.org/10.4103/lungindia.lungindia_794_20 
Taboada, M., Gonzalez, M., Alvarez, A., Gonzalez, I., Garcia, J., Eiras, M., Vieito, M. D., Naveira, A., Otero, P., Campana, O., Muniategui, I., Tubio, A., Costa, J., Selas, S., Carinena, A., Martinez, A., Veiras, S., Aneiros, F., Caruezo, V., \& Alvarez, J. (2021). Effectiveness of Prone Positioning in Nonintubated Intensive Care Unit Patients with Moderate to Severe Acute Respiratory Distress Syndrome by Coronavirus Disease 2019. Anesth Analg, 132(1), 25-30. https://doi.org/10.1213/ANE.0000000000005239

Tobin, M. J., Laghi, F., \& Jubran, A. (2020). Caution about Early Intubation and Mechanical Ventilation in COVID-19. Ann Intensive Care, 10(1), 78. https://doi.org/10.1186/s13613-020-00692-6

Valesky, W., \& Chow, L. (2020). Prone Positioning for Acute Respiratory Distress Syndrome in Adults. Acad Emerg Med, 27(6), 520-522. https://doi.org/10.1111/acem.13948

Wang, C., Wang, Z., Wang, G., Lau, J. Y., Zhang, K., \& Li, W. (2021). COVID-19 in Early 2021: Current Status and Looking Forward. Signal Transduct Target Ther, 6(1), 114. https://doi.org/10.1038/s41392-021-00527-1

Wendt, C., Mobus, K., Weiner, D., Eskin, B., \& Allegra, J. R. (2021). Prone Positioning of Patients with Coronavirus Disease 2019 Who Are Nonintubated in Hypoxic Respiratory Distress: Single-Site Retrospective Health Records Review. J Emerg Nurs, 47(2), 279-287 e1. https://doi.org/10.1016/j.jen.2020.12.006

WHO. (2021). Clinical Management of COVID-19: Living Guidance (pp. 1-81). WHO

Winearls, S., Swingwood, E. L., Hardaker, C. L., Smith, A. M., Easton, F. M., Millington, K. J., Hall, R. S., Smith, A., \& Curtis, K. J. (2020). Early Conscious Prone Positioning in Patients with COVID-19 Receiving Continuous Positive Airway Pressure: A Retrospective Analysis. BMJ Open Respir Res, 7(1). https://doi.org/10.1136/bmjresp-2020-000711

Wormser, J., Romanet, C., \& Philippart, F. (2021). Prone Position in Wards for Spontaneous Breathing COVID-19 Patients: A Retrospective Study. Ir J Med Sci. https://doi.org/10.1007/s11845-020-02479-x

Wu, Z., \& McGoogan, J. M. (2020). Characteristics of and Important Lessons from the Coronavirus Disease 2019 (COVID-19) Outbreak in China: Summary of a Report of 72314 Cases from the Chinese Center for Disease Control and Prevention. JAMA, 323(13), 1239-1242. https://doi.org/10.1001/jama.2020.2648 